\title{
Correction to: The modification effect of temperature on the relationship between air pollutants and daily incidence of influenza in Ningbo, China
}

Rui Zhang ${ }^{1}$, Yujie Meng ${ }^{1}$, Hejia Song ${ }^{2}$, Ran Niư ${ }^{3}$, Yu Wang ${ }^{2}$, Yonghong $\mathrm{Li}^{2^{*}}$ (1) and Songwang Wang ${ }^{1 *}$

\section{Correction to: Respir Res (2021) 22:153} https://doi.org/10.1186/s12931-021-01744-6

The original version [1] of this article unfortunately contained a mistake. The presentation of Supplementary Fig. S1 was incorrect. The correct version is given (Additional file 1: Figure S1). The original article has also been corrected.

\section{Supplementary Information}

The online version contains supplementary material available at https://doi. org/10.1186/s12931-021-01831-8.

Additional file 1: Figure S1. Relative risk of daily incidence of influenza associated with temperature on lag $0-30$ days, $\mathrm{O}_{3}$ on lag $0-7$ days, $\mathrm{PM}_{2.5}$ on lag 0-14 days, $\mathrm{PM}_{10}$ on lag 0-14 days and $\mathrm{NO}_{2}$ on lag 0-14 days.

\begin{abstract}
Author details
${ }^{1}$ Chinese Center for Disease Control and Prevention, Beijing 102206, China. ${ }^{2}$ National Institute of Environmental Health, Chinese Center for Disease Control and Prevention, No 7. Panjiayuan Nanli, Chaoyang District, Beijing 100021, China. ${ }^{3}$ National Institute for Nutrition and Health, Chinese Center for Disease Control and Prevention, Beijing 100050, China.
\end{abstract}

Published online: 07 September 2021

Reference

1. Zhang R, Meng Y, Song H, Niu R, Wang Y, Li Y, Wang S. The modification effect of temperature on the relationship between air pollutants and daily incidence of influenza in Ningbo, China. Respir Res. 2021;22:153.

\section{Publisher's Note}

Springer Nature remains neutral with regard to jurisdictional claims in published maps and institutional affiliations.
The original article can be found online at https://doi.org/10.1186/s12931021-01744-6.

*Correspondence: liyonghong@nieh.chinacdc.cn; wangsw@chinacdc.cn

${ }^{1}$ Chinese Center for Disease Control and Prevention, Beijing 102206,

China

${ }^{2}$ National Institute of Environmental Health, Chinese Center for Disease

Control and Prevention, No 7. Panjiayuan Nanli, Chaoyang District,

Beijing 100021, China

Full list of author information is available at the end of the article

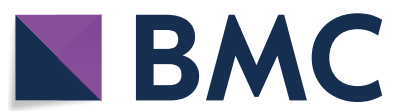

(c) The Author(s) 2021. Open Access This article is licensed under a Creative Commons Attribution 4.0 International License, which permits use, sharing, adaptation, distribution and reproduction in any medium or format, as long as you give appropriate credit to the original author(s) and the source, provide a link to the Creative Commons licence, and indicate if changes were made. The images or other third party material in this article are included in the article's Creative Commons licence, unless indicated otherwise in a credit line to the material. If material is not included in the article's Creative Commons licence and your intended use is not permitted by statutory regulation or exceeds the permitted use, you will need to obtain permission directly from the copyright holder. To view a copy of this licence, visit http://creativecommons.org/licenses/by/4.0/. The Creative Commons Public Domain Dedication waiver (http://creativeco mmons.org/publicdomain/zero/1.0/) applies to the data made available in this article, unless otherwise stated in a credit line to the data. 